UDC 347.238.8:929.52 OBRENOVIĆ(443.611)"1906”

https://doi.org/10.18485/ms_zmslu.2021.49.10

Стручни рад

Гордана С. Крстић Фај ${ }^{*}$

\title{
АУКЦИЈА У ПАРИЗУ 1906. ГОДИНЕ СА ЗАОСТАВШТИНОМ СРПСКИХ КРАЉЕВА МИЛАНА И АЛЕКСАНДРА ОБРЕНОВИТА
}

\begin{abstract}
САЖЕТАК: Након Мајског преврата 1903. године део заоставштине Обреновића продавао се на аукцијама у Србији и у иностранству. Полазећи од француске литературе, у раду се осветљава аукција одржана 16. и 17. фебруара 1906. године у париском Друоу (Drouot), која је претежно обухватила уметничка дела, али и један број разноврсних предмета из заоставштине Милана и Александра Обреновића. Каталог аукције драгоцен је прилог за проучавање садржаја некадашње краљевске збирке. Амброаз Волар (Ambroise Vollard), познати париски трговац, галериста и издавач, откупио је на аукцији неколико дела а Етјен Моро Нелатон (Étienne Moreau-Nélaton), чувени париски колекционар, пажљиво ју је пратио, уписујући излицитиране суме у каталог, који је поклонио Националној библиотеци Француске у Паризу. Аукцију је пропратила париска штампа.
\end{abstract}

КљУЧНЕ РЕЧИ: аукција у Паризу са заоставштином Милана и Александра Обреновића, Милан Обреновић, гроф од Такова, Александар Обреновић, колекција Обреновића, Амброаз Волар, Етјен Моро Нелатон.

Након убиства Александра и Драге Обреновић 1903. године власт у Србији преузели су Карађорђевићи. Део покретне заоставштине свргнуте династије потом се аукцијски продавао у Србији и иностранству. Наталија Обреновић покренула је аукције једног дела покретне имовине у Бечу 1905. и 1906. године (NACHLASS 1905; ВукЕлит 2017: 10, 13-15; 2019: 38, 44-46) и у Паризу 1906. и 1926. године (TABLEAUX MODERNES 1906; КРСТИЋ-ФАЈ 2015: 276-277). ${ }^{1}$

\footnotetext{
* самостални истраживач, gordanazo@yahoo.com

${ }^{1}$ Наталија Обреновић је део наслеђа поклонила фрушкогорском манастиру Крушедолу, Народном и Природњачком музеју, блиским особама и поштоваоцима свргнуте династије (ВукЕлИЋ 2017: 10; 2019: 38). У комисији за попис краљевске збирке 1903. године био је и Богдан Поповић, који је уместо хонорара узео један Дегаов пастел, како је посведочио Борис Лоски (Boris Lossky) (према LEMOISNE 19846: 582). Пастел на браон папиру (око 1889-92, дим. $49 \times 38 \mathrm{~cm}$ ) потписан је доле лево (Ibidem). По сведочењу
} 


\section{CATALOGUE

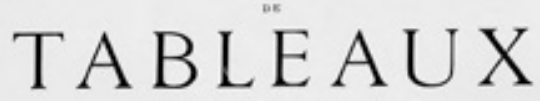 \\ MODERNES

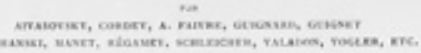

Aquarelles, Pastels, Dessins

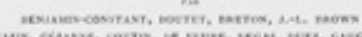

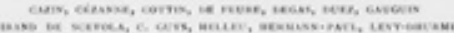

PORCELaines, aRgenterie, ETOFFES

objots vaslia - Xenstes

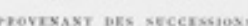

Des Rois MILAN et ALEXANDRE de Serbie

Ex dont la vente surs lieg a Paris

HOTEL DROUOT, SALLE N 6

Les Vendredi 16 et Samedi 17 Fivrier 1906 $2+$ Arans

cosmum

PAUL CHEVAYA IR , GEORGES PETIT

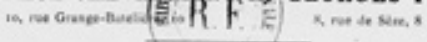

EXPositió PUBLIQUE

Le Jeudi 15 Tivrier 1906, de 1 houre 1/2 a 5 haures 1/2

Сл. 1. Каталог аукције, унутрашња страна. Национална библиотека Француске, Париз.

(Извор: gallica.bnf.fr / BnF)

Прва париска аукција са наслеђем Обреновића уследила је убрзо након прве бечке аукције (10-16. октобар 1905). Одржана је у петак и суботу, 16. и 17. фебруара 1906. године у Друоу (Drouot), у сали бр. 6, са почетком у 14 часова (сл. 1). 3а реализацију су били задужени аукционар Пол Шевалије (Paul Chevallier) и експерт Жорж Пети (Georges Petit). ${ }^{2}$ Предаукцијска изложба приређена је у четвртак 15. фебруара, од 13.30 до 17.30 часова. Продаја је највећим делом обухватила дела ликовне уметности: „модерне” слике, аквареле, пастеле, графике и цртеже, претежно радове француских и других западноевропских аутора, као и мањи број разноврсних предмета: вазе, тањире, сервисе за ручавање и друго од декоративног порцелана, два свећњака од посребрене бронзе, лавор и бокал од сребра, рам од сребрног филиграна, конзолу од позлаћеног дрвета, намештај са инкрустрацијама од седефа, два тепиха, групу оријенталних и других тканина: прекриваче за кревет, паное и друго (TABLEAUX MODERNES 1906; КРСТИЋ-ФАJ 2015: 276-277). Аукцију су најављивали Журнал geз ар (Le Journal des arts) и Кроник gез ар е gе ла кириозийе (La Cronique des arts et de la curiosité). ${ }^{3}$

Каталог аукције садржи 218 одредница, од којих је 210 посвећено уметничким делима. Каталогизовани су 32 слике, 75 акварела, 56 пастела, 44 цртежа и две графике, док је број 210 обухватио групу некаталогизованог материјала: слике, аквареле и друго. Разноврсни предмети сврстани су под осам каталошких бројева, који су претежно обухватили више од једног објекта. Каталог не садржи фотографије ни

Бориса Лоског, Богдан Поповић је из краљевске колекције поседовао и цртеж Фелисијана Ропса (Félicien Rops) (према БОшњАК 2010: 506).

2 Адреса Пола Шевалијеа гласила је: Улица Гранж Бателијер број 10 (10, rue Grange-Batelière) a адреса Жоржа Петија: Улица Сез број 8 (8, rue de Seize). У галерији Жоржа Петија су југословенски уметници 1932. године приредили своју изложбу.

3 Журнал gез ар најављивао је аукцију 31. јануара, 3, 7, 10. и 14. фебруара, а Кроник gез ар е gе ла кириозитие 3. фебруара 19о6. године. 
процењене вредности, односно почетне цене понуђеног садржаја. Уметничка дела раздељена су по врстама у пет поглавља: Слике, Акварели, Пастиели, Цриеежи и Графике. У оквиру сваког поглавља наведена су презимена аутора по абецедном реду и потом под редним бројевима називи дела, место сигнатуре, димензије и евентуално: подлога, ознаке на полеђини, потврда о пореклу или додатна појашњења технике. Каталог, као својеврсни инвентар једног дела краљевске збирке, сведочи о њеној хетерогености. Драгоцен је прилог за проучавање садржаја колекције краља Милана. Њен обим, садржај и историјат набавки нису довољно познати ни проучавани, а она у Београду није ни јавно излагана (БОШњАК 2010: 505, 507).

У примерку каталога који се чува у Националној библиотеци Француске у Паризу су, уз један број каталошких јединица, руком записане излицитиране суме у францима, док један број цена сазнајемо и из париске штампе. Купци су на излицитирану суму плаћали и додатну таксу од десет процената (TABLEAUX MODERNES 1906: 2). Једноставни овални печат са текстом: DON MOREAU NELATON 1927, отиснут на предњој корици каталога, сведочи да га је Националној библиотеци Француске 1927. године поклонио Етјен Моро Нелатон (Étienne Moreau-Nélaton, 1859-1927), чувени париски колекционар, сликар и историчар уметности (сл. 2). ${ }^{4}$ На основу печата може се закључити да је Етјен Моро Нелатон, један од највећих донатора француских музеја уопште, присуствовао аукцији заоставштине Обреновића 1906. године у Паризу и да ју је пажљиво пратио, записујући излицитиране суме у каталог. Можда је том приликом нешто и откупио.

Каталог аукције сведочи да су се у збирци Милана и Александра Обреновића међу

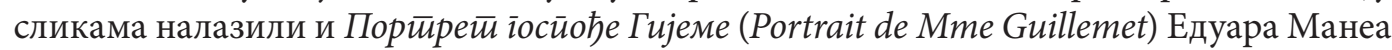

4 Етјен Моро Нелатон је већину дела из своје чувене колекције поклонио музеју Лувру (Louvre) 1906. године, где су она изложена, као и у музеју Opсеј (Orsay). Поседовао је и Манеов Доручак на йрави (KoECHLIN 1927). 


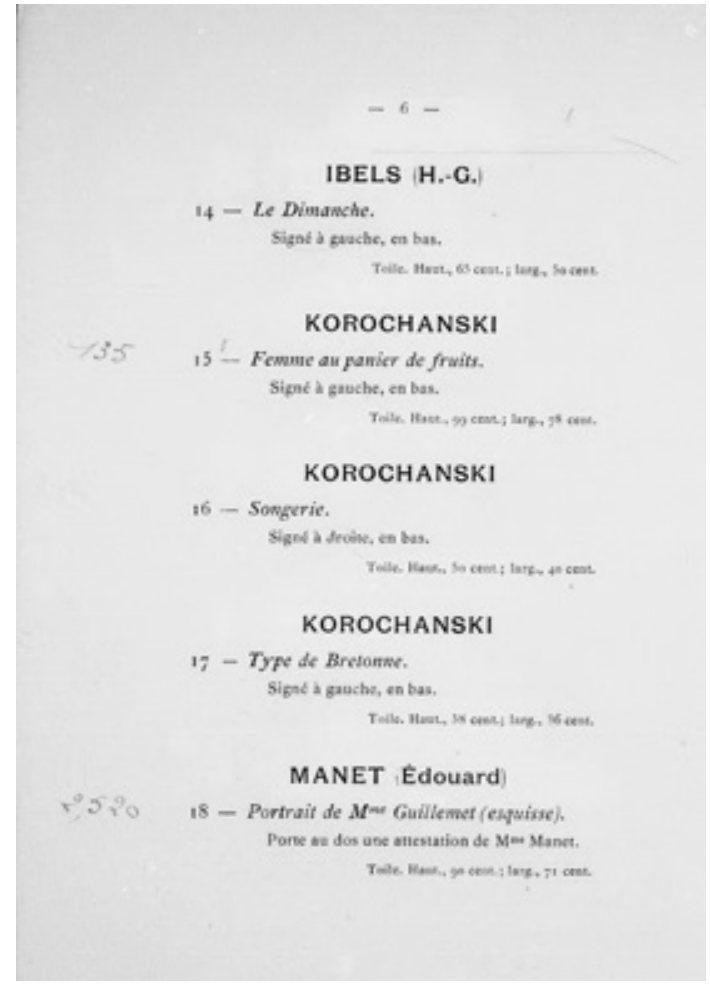

Сл. 3. Страна каталога аукције са сликом Поритрети іосйође Гијеме (Portrait de Mme Guillemet) Едуара Манеа (Edouard Manet). Национална библиотека Француске, Париз. (Извор: gallica.bnf.fr / BnF)
(Edouard Manet) (сл. 3), ${ }^{5}$ излицитиран на 2520 франака, Цвеће (Fleurs) Сизан Валадон (Suzanne Valadon), На обалама Исланga (Sur les côtes d'Islande) Ивана Аjвазовског (Ivan Aivasovsky / Иван Айвазовский) излицитиран на 780 франака. Међу акварелима су била и четири рада Пола Сезана (Paul Cézanne): Пејзаж (Раysage), излицитиран на 1300 франака, Зелене билке (Plantes vertes), излицитиране на 360 франака, Брескве (Pêches), излицитиране на 850 франака, и Мрӣва йрироgа (Nature morte), излицитирана на 400 франака, од Алфонса Myхе (Alphonse Mucha) две Aлеīopuje (Allégories) и Франиуско-руске йрославе (Les Fêtes franco-russes) ${ }^{6}$ и четири гваша Чейири іоguшюа gоба (Les Quatre saisons), излицитирана на 370 франака. Међу пастелима били су и Плесачица йри йоалетии (Danseuse à sa toilette) Едгара Дегаa (Edgar Degas), излицитирана на 1650 франака, потом три рада Пола Гогена (Paul Gauguin): Глава Кинеза (Tête de Chinois), Тахићанка (Tahitienne) и Жена из Бретиане (Bretonne), Пејзаж (Paysage) Клода Монеа (Claude Monet), излицитиран на 430 франака, Mлаge geвојке (Jeunnes filles) Огиста Реноара (Auguste Renoir), излицитиране на 1000 франа-

ка, и Фарма (La Ferme) Алфреда Сислија (Alfred Sisley), излицитирана на 350 франака. Међу цртежима биле су и Вешитице око ват̄pe (Sorcières autour d'un feu) Гистава До-

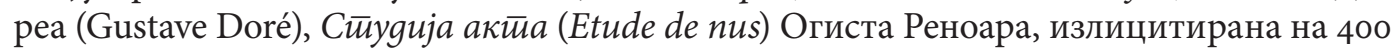
франака, Ogмор (Repos) Сизан Валадон (Suzanne Valadon) и три рада Теофила Стајн-

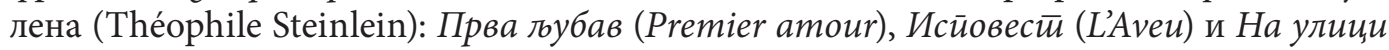

5 Слика није потписана, на позадини је имала потврду госпође Мане (TABLEAUX MODERNES 1906: 6; TABARANT 1947: 334). Позната је и као Жена која сеgи на канайеу (Femme assise sur un canapé) и сматра се да представља супругу Жила Гијемеа (Jules Guillemet), коју је Мане приказао и на другим, значајнијим радовима (TABARANT 1947: 334). Слику је фотографисао Фернан Лошар (Fernand Lochard) 1883. године (LOCHARD 1883-1884: 82; TABARANT 1947: 334). Репродукција је публикована у монографијама посвећеним делу Едуара Манеа (TABARANT 1947: 612, сл. 308; VENTURI, ORIENTI 1967: 108, сл. 254).

${ }^{6}$ Скицу за овај рад вид. на: https://archive.org/details/frick-31072001412883/page/n33/mode/2up 
(Dans la rue). Графика Едгара Дегаa (Edgar Dega) Toалетиа (La Toilette) излицитирана је на 275 франака а Жене (Femmes) на 215 франака (TABLEAUX MODERNES 1906, КрстиЋ-ФАЈ 2015: 277)?

\section{Одјеци у савременој париској штампи и откупи}

Аукција са заоставштином Обреновића 1906. године у Паризу била је несвакидашњи догађај и привукла је пажњу париске штампе. Лист Ла йpec (La Presse) предвиђао је да ће продаја ове „лепе” колекције бити прави париски догађај који ниједан сноб неће пропустити (FLÛTE 1906: 2). Фuі̃apo је навео како је краљ Милан волео да посећује уметнике и сабрао је „лепу” колекцију модерних дела, сматрајући да ће предаукцијска изложба у Друоу привући посебну пажњу (Le MASQUE DE FER 1906: 1).

Пейи Паризијен (Le Petit Parisien) 17. фебруара 1906. године у тексту „Успомене из конака" (сл. 4), извештавајући са првог дана аукције, каже како је Друо подсетио на крваву београдску трагедију од пре три године (РetiTJEAN 1906: 4). Продаја предмета из „злокобног” конака, у ком су убијени краљ Александар и краљица Драга, предузета је по захтеву наследника. Наводно је један представник руског министра финансија послат да нешто откупи и покушао је да добије додатне информације и доказ о пореклу предмета. Међутим, речено му је само то да су им предмети послати из Београда под таквим условима да никакве сумње о њиховом пореклу не може бити.

У истом тексту, претерујући се каже да већина предмета нема другу вредност од свог порекла и као доказ наводи се ниска сума од 23.460 франака, постигнута првог дана продајом слика, акварела и неколико пастела. Другог дана продавали су се преостали пастели, цртежи, графике и разноврсни предмети. Намена намештаја са седефним инкрустрацијама

\section{SOUVENIRS DU KONAK}

A rHotal Dronot, - On vend des Objets provenant de la Succession des Rois Milan et Alexandre de Serbie. - I'Amie de la Reine Dràga. - Faibles Enchères.

La sanglante tragédie qui se déroula à Belgrade, il y a trois ans, a été évoquée, hier, a l'hotel Drouot : M. Paul Chevallier, commissaire-priseur, assisté de $\mathrm{M}$. Georges Petit a commencé la vente d'objets provenant du sinistre konak, dans lequel, une muit, Alexandre de Serbie et sa femme, la reine Draga, furent égorgés par des officiers. Cette vente a lieu a la requete des béritiers des rois Milan et Alexandre; mais, a rétude de M. Chevallier, on ne fournit aucun autre détail. Et, hier, un délégué du ministre des Finances russes, venu pour demander quelques renseignements complémentaires, n'en put, lui-meme, oblenir plus que moi. - Jai reçu la mission dacheter quelque chose, dit-il à un employé de M. Paul Chevallier, et je désirerais avoir une preuve de rauthenticité de l'origine des objets mis aux enchères.

A vec un sourire énigmatique, le scribe se conlenta de répondre :

Сл. 4. Текст „Успомене из конака“, Пейи Паризијен (Le Petit Parisien), 17. фебруар 1906, стр. 4. Национална библиотека Француске, Париз. (Извор: gallica.bnf.fr / BnF)

\footnotetext{
7 Наведене суме забележене су руком у каталогу аукције који је у Националној библиотеци Фран-
} цуске. 


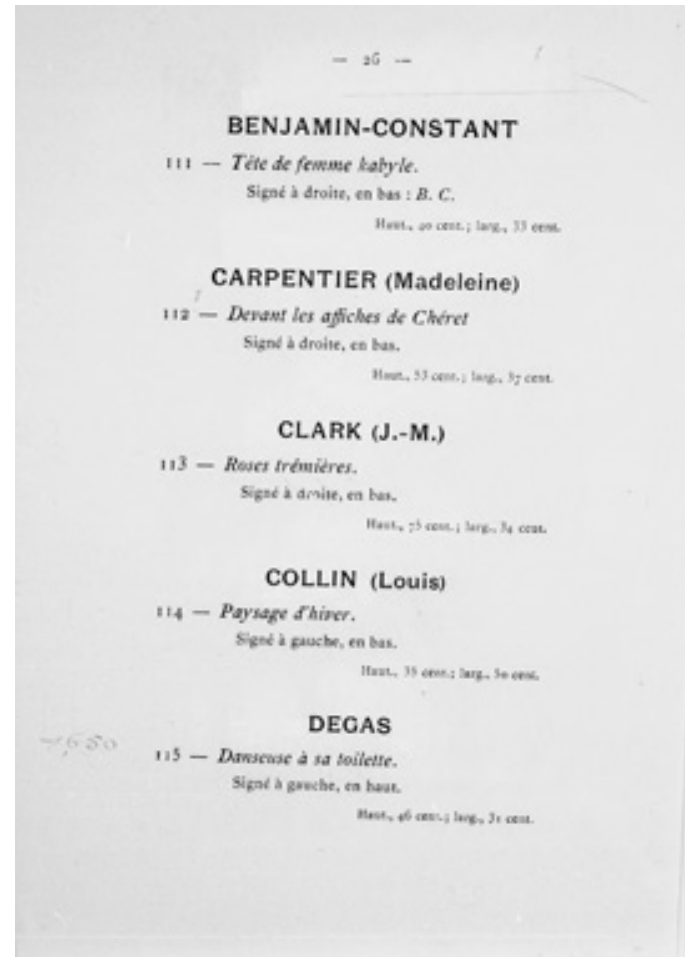

Сл. 5. Страна каталога аукције са пастелом

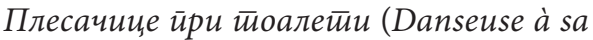
toilette) Едгара Дегаa (Edgar Degas). Национална библиотека Француске, Париз. (Извор: gallica.bnf.fr / BnF)

и тешким вратима која се отварају ка „ужасном низу сличица од моделованог и бојеног воска” оцењена је као „нејасна”. Даље се претерујући каже како су понуђене „тужне рите једне породице којој добар укус није био доминантан квалитет”. Уметничка дела, или она која претендују да то буду, представљају еклектичан избор који иде чак до најпретераније особености, а у збирци су заступљена и одлична дела.

Пейи Паризијен даље наводи како у сали где се одвијала аукција није било велике гужве. Релативно малобројну публику чинили су пре свега трговци, али су се ипак запажала и „нека лепа лица, неколико свежих тоалета и господа одликована Легијом части”. Било је и америчких љубитеља уметности, коначно и једна група Срба „зеленкастих у лицу”, који су са највећом пажњом пратили ток лицитирања. Један од њих најпажљивије је записивао цифре у свој каталог. Извесна „још увек млада жена” доминирала је висином у првом реду, „опијена” представом која се пред њом одвијала. Говоркало се да је то пријатељица покојне краљице Драге. Показивали су јој главна дела која је она посматрала са видним емоцијама. Купила је само један пастел за 22 франка, успомену у складу са скромним могућностима.

У тексту се даље наводи да су лицитирања била слаба: слика Caн (Sommeil) Абела Февра (Abel Faivre) достигла је 205 франака, Расйоgела суйe (La Distribution de soupe) Нале Пусана (Nallet-Poussin) 29 франака а Цвеће (Fleurs) Сизан Валадон 30 франака. Поједини радови премашили су процењене вредности: акварел Пејзаж (Paysage) Пола

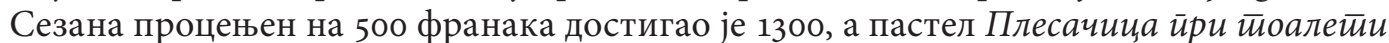
(сл. 5) Едгара Дегаа је од процењених 400 достигао 1650 франака. Нека дела продата су по знатно нижим ценама од процењених: слика Броgолом (Un naufrage) Мола Нила Петерсена (Mols Niels Petersen) процењена на 2000 франака једва је излицитирана на 1080 франака. ${ }^{8}$ Леиееза (Eventail) Жана Форена (Jean Forain) излицитирана је на

\footnotetext{
8 у каталогу је записана сума од 1050 франака.
} 
240 франака а Вилетов (Willette) акварел Краль йuje (Le Roy Boit) са посветом „Госпођи Ле Фијел (Le Filleul), успомена на пријатељство друга Пјероа (Pierrot)" на 155 франака. Због врло ниске цене присутни су сматрали да је тај акварел „поклоњен”. Пейи Паризијен на крају констатује како се продајом 152 дела расула „сирота” колекција краља Милана и његовог сина, у којој „заиста није било превише кукоља".

Извештавајући о другом дану аукције, Петии Паризијен наводи како је у Друоу било још мање публике него првог дана (ANONYME 1906б: 2; сл. 6). Пријатељица краљице Драге, која је изазвала толико коментара, није поново дошла, као ни амерички поклоници уметности. Само су Срби, „пажљиви и озбиљни”, поново заузели своја места а лицитирање је било „екстремно слабо”. Цртеж Берачииза аліи (Cueilleuse de varechs) Анрија Бутеа (Henri Boutet) излицитиран је на 18 франака, Жена са йyбом (Femme à la houpette) и Жена из нароga (Femme du peuple) Кутиријеа (Couturier) заједно на 10 франака

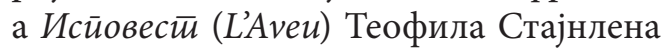
(Steinlen) на 14 франака. Казанов (Cazin) „леп” цртеж Млин (Le Moulin) достигао је 305 франака а Вешишице око ватире Гистава Дореа 115 франака...

Ни понуђени предмети нису постигли више суме. Бокал и лавор од сребра достигли су само 310 франака. Извесна дама излицитирала је конзолу од позлаћеног дрвета и намештај са инкрустрацијама од седефа и сличицама од бојеног воска на 460 франака. Једино је рам од сребрног филиграна достигао „озбиљну” суму од 1030 франака. Оријенталне тканине и тепихе већим делом купио је један од присутних Срба. Првог дана продаје остварено је 23.460 франака, другог само 10.418, што укупно чини 33.878 франака. Када се одбију трошкови паковања, транспорта, складиштења, осигурања, продаје и осталог, мало је новца преостало, закључује Пеиии Паризијен.

Лист Майан (Le matin) 17. фебруара у тексту „Последње олупине једног краљевског достојанства” констатује шароликост краљевске збирке и неочекивано „помирење” у каталогу (ANONYME 1906а: 2). Наводи да су у сали били бројни странци, нарочито Срби, који су пре изгледали као да желе да понесу успомене пуне поштовања 
или пак националне реликвије, а не да купе слике. Майан закључујући каже: „Величина и декаденција једног краљевства”. Тем (Le Temps) између осталог наводи: „Самим погледом на уметничке хороре наслагане тамо, могао се стећи утисак о менталитету овог трагичног владара трагичне оперете, који је у исто време ултрапариски и још помало дивљи" (CLARETIE 1906: 2).

Нарочито критички настројен текст у листу Меркур ge Франса (Mercure de France) оцењује да „неуспех” аукције са заоставштином Обреновића не треба приписивати аукционару и експерту (DAURELLE 1906: 312-313). Како се наводи, свако је мање-више приметио или знао краља Милана, који је „био варварин, имао је извесну привлачност и одсуство укуса. Куповао је стихијски шта је стигао, следећи добре или лоше савете или мање-више компетентна мишљења из штампе. Крочио је кроз живот без културе, без принципа и без метода. Његова колекција била је модерна 'папазјанија', мешавина дела врло различитих уметника.” Лицитирања су била „прилично јадна”. Pagocī y йољу (Plaisir champêtre) Абела Февра излицитирана је на 150 франака, Жена са корйом воћа (Feme au panier de fruit) Корочанског (Korochanski) на 135 франака, Глава сйyguje (Tête d'étude) Елеа (Helleu) на 100 франака... На крају текста ипак се одаје признање краљу Милану за то што је храбро куповао дела живих уметника, док су француски колекционари куповали „старо”, нарочито дела из XVIII века, слепо следећи моду и руководећи се само жељом за тренутачном шпекулацијом.

Фиіаро у извештају са аукције закључује како то никако није била „велика” продаја. Пажњу је изазвала јер је понуђена збирка припадала краљевима, целина није ништа сјајно, ништа краљевски, обухватала је многе слике малих димензија, многе пријатне крокије... Лицитирања нису била значајна и цене су биле „добре” (VALLEMONT 1906: 5). Кроник gез ар е gе ла кириозите између осталог наводи да је Мишетијева (Michetti) слика Дивљачић (Sauvageon) достигла 600 франака, Браунов (Brown) акварел Боїазов йролаз (Le Passage du gué) 830 франака, акварел Плесови из Океаније (Danses d'Océanie) Рошгроса (Rochegrosse) 6оо франака, Бертсоенов (Baertsoen) пастел Дуж канала (Au bord du canal) 420 франака итд. (ANONIM 1906в: 64; M 1906: 2).

Амброаз Волар, ${ }^{9}$ чувени париски трговац уметнинама, галериста и издавач, потврдио је да је „булеварска” штампа поводом постхумне продаје колекције Милана Обреновића у Друоу имала још једну прилику да „слави” њен еклектизам (VOLLARD 1937: 131). У личној архиви забележио је да је током првог дана аукције купио три пастела: Mrage geвојке (Jeunes filles) Огиста Реноара за 1000 франака, Сереову (Serret) Шейтьу (La Promenade) за 105 франака и Cūapujy cecūpy (La Grande Soeur) за 72 франка, а другог дана диптих у техници пастела Енитеријер сељанина (Intérieur de paysan) Леона Бартоломеа (Léon Bartholomé) за 80 франка, две Дегаове графике: Toалейy (La Toilette) за 275 франака и Жене (Femmes) за 215 франака, као и групу некаталогизованих слика, акварела и осталог за 55 франака (према RABINOW, WARMAN 2007: 218).

9 Секретар Амброаза Волара касније је био Ерих Шломовић. Део његове колекције је у Народном музеју у Београду. 
Амброаз Волар упознао је Милана Обреновића када га је бивши српски краљ посетио са колекционаром Изаком де Камондоом (Isaac de Camondo). Купио је тада слику Смрй кравама! (La mort aux Vaches!) Анрија Груа (Henry Groux), коју је недељу дана касније заменио за неколико Сезанових акварела ${ }^{10}$ (VOLLARD 1915: 68, 70; 1937: 128-129), можда баш оних који су продати на париској аукцији 19o6. године. Лисјен Гиро (Lucien Guiraud) купио је Порйрет̄ іосйође Гијеме, који је касније доспео у колекцију Жоржа Менијеа (Georges Menier) (TABARANT 1947: 334). ${ }^{11}$

Колико су цене уметничких дела из српске краљевске колекције 1906. године у Паризу биле ниске сведочи и каснија препродаја Дегаове Плесачище йри йоалетии (Danseuse à sa toilette), коју је забележио париски Журнал (Le Journal). Овај пастел купљен на аукцији 1906. године за 1650 франака продат је 1932. године за 50.500 франака (LANG 1932: 2). Цена овог рада 26 година касније значајно је премашила укупну

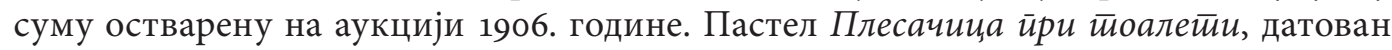
око 1879. године, доспео је у париску колекцију Жила Строса (Jules Strauss) a 1932. године код Пола Розенберга (Paul Rosenberg), чувеног париског трговца и галеристе (LemOISNe 1984a: 306, No 546).12 Ово је прво дело Едгара Дегаа које је купио Милан Обреновић 22. марта 1895. године за 1500 франака од Пола Диран Ријела (Paul Durand-Ruel), једног од најпознатијих париских трговца уметнинама (према LOIRETTE 1991: 608, 794). ${ }^{13}$ Милан Обреновић касније је купио још пет Дегаових радова: 22. маја 1896. године од Пол Диран Ријела једну лепезу за 3000 франака, а од Амбоаза Волара 10. октобра 1895. године Жену која сеgи и чешта се (Femme assise se peignant) за 900

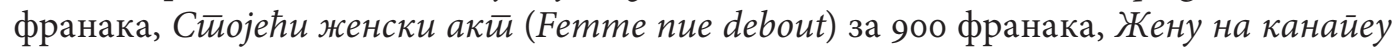
(Femme au canapé) за 540 франака и 31. марта 1896. године један цртеж за 750 франака (Ibid.). ${ }^{14}$

На фотографијама ентеријера и појединачних предмета из Старог двора у Београду, које је снимио Љубиша Ђонић 1904-1905. године, уочавају се оријенталне и друге тканине, као и један дводелни параван (Вукелић, ПерАћ, Томић 2019: сл. 57-63). Може се претпоставити да оријенталне и друге тканине и параван који су се нашли

10 По наводу Амброаза Волара, „пренаглашени” париски манири Милана Обреновића одавали су странца, тежио је да ода утисак да га интересује све што је ново у уметности и замолио је Изака де Камондоа да га поведе на места „напредне уметности”.

${ }_{11}$ По Садебијевом (Sotheby) наводу, слика је била и у власништву Вилденштајна, чувеног париског трговца уметнинама, а потом је опет мењала власнике (<https:/www.sothebys.com/en/auctions/ ecatalogue/2018/impressionist-modern-art-evening-sale-no9930/lot.59.html >).

12 Садеби наводи да је овај пастел 1906. године откупила госпођа Мије (Муе), а потом је доспео у колекцију Жила Строса (http://www.sothebys.com/ru/auctions/ecatalogue/20og/impressionist-modern-artevening-sale-no8587/lot.23.pricehl.html). Продају 1932. године организовала је галерија Жоржа Петија, аукцију је пратио каталог (https://catalogue.bnf.fr/ark:/12148/cb36524574c).

${ }_{13}$ Пол Диран Ријел је Плесачииу йри йоалетии откупио на аукцији претходне 1894. године из познате колекције Теодора Диреа (Théodore Duret). У каталогу ове аукције је под бројем 15 (CATALOGUE 1894: 16).

${ }_{14}$ Анри Лоарет се позива на архиве Пола Диран Ријела и Амброаза Волара. На помоћи око увида у књигу Анрија Лоарета најсрдачније захваљујем колегиници Марији Богдановић. 
на аукцији у Паризу 1906. године потичу из краљевог арапског салона ${ }^{15}$ и суседне билијарске собе, из београдског Старог двора. Судећи по седефним инкрустрацијама, можда је и намештај са тешким вратима и сличицама од воска припадао арапском салону.

\section{Отуђена сведочанства - ненадокнадив губитак}

Непопуларност убијеног краљевског брачног пара Александра и Драге свакако је значајно допринела одлуци наследнице Наталије Обреновић да део покретног наслеђа понуди на продају ван Србије. Аукцијска продаја краљевске заоставштине у Паризу 1906. године била је несвакидашњи догађај, који је с разлогом изазвао пажњу. Најаве и извештаји у штампи објављивани су и на насловним странама а опречне оцене краљевске колекције кретале су се од „лепе збирке” до „модерне папазјаније”. Штампа је забележила и интересантне детаље и цене појединих дела.

Док су на аукцији у Бечу 1905. године уметничка дела представљала мањи део понуђеног садржаја, на париској аукцији 1906. године чинила су главнину. Поређењем каталога ових аукција закључује се да оне нису нудиле идентична дела, која су очигледно разврстана према процењеним интересовањима бечке и париске публике. На париској аукцији најзаступљенија су била дела француских и других западноевропских уметника, али је било и радова неколико руских и средњоевропских аутора.

Приход са аукције у Паризу 1906. године био је слаб, док би данашња вредност продатог ансамбла била неупоредиво значајнија. На највишу суму од 2520 франака

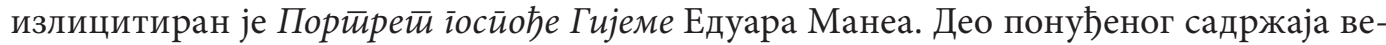
роватно су откупили трговци ради препродаје, потом колекционари ради укључивања у личне збирке или пак поштоваоци свргнуте династије као успомену. Највећи део уметничких дела и предмета продат је страним купцима и данас им је тешко ући

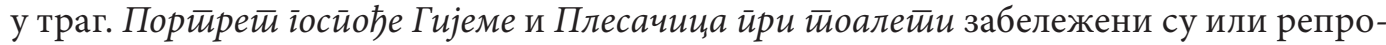
дуковани у монографијама посвећеним Едуару Манеу и Едгару Дегау, каталозима аукција и фото-албуму Фернана Лошара (Fernand Lochard).

Каталог париске аукције из 1906. године својеврсни је инвентар једног дела некадашње краљевске збирке и драгоцен је прилог за утврђивање и проучавање њеног садржаја. Колекцију Обреновића највећим делом формирао је Милан Обреновић након силаска са трона 1889. године, када је у Паризу боравио под титулом „грофа од Такова”. У Паризу је посећивао галеристе и уметнике у друштву колекционара Изака де Камондоа, показујући значајно интересовање за „напредну” уметност. Куповао је дела савремених стваралаца, без намере за шпекулисањем или профитом и формирао је хетерогену колекцију са делима већег броја уметника. Након свргавања Обреновића са власти њихова колекција је расформирана претежно продајом, нешто је

15 Краљ Милан је арапски салон донео са путовања по Блиском истоку 1889. године (ВукЕлић 2019: 40). 
поклоњено а можда и украдено или уништено током Мајског преврата или каснијих ратних сукоба.

Отуђена уметничка дела и предмети из заоставштине покојних српских краљева Милана и Александра Обреновића својеврсна су сведочанства о њиховим естетским критеријумима, наклоностима, активностима и начину живота, те поред уметничке и материјалне имају и културно-историјску вредност. Уметничка дела илуструју колекционарске активности краља Милана и његове везе са савременим европским уметницима, трговцима и колекционарима. Да су поменута сведочанства након Мајског преврата 1903. године доспела у Народни музеј у Београду, заједно са другим поклонима Наталије Обреновић, била би драгоцени прилози, а њихово отуђење је ненадокнадив губитак.

\section{ПОПИС КАТАЛОГИЗОВАНИХ УМЕТНИЧКИХ ДЕЛА ${ }^{16}$}

\section{СЛИКЕ}

Ајвазовски (Aivasovsky): 1. На обалама Исланga (Sur les côtes d'Islande), платно, потписано доле десно, $35 \times 57,5 \mathrm{~cm}$ (18о франака).

Кајо Жорж (Callot Georges): 2. Мала слушкиња (La Petite servante), платно, потписано горе лево, $51 \times 40 \mathrm{~cm}$.

Корде (Cordey): 3. Привезане gереїлије (Péniches ammarrées), платно, потписано доле лево, $40 \times$ $60 \mathrm{~cm} .4$. Месечина (Clair de lune), платно, потпис доле десно, $32 \times 40 \mathrm{~cm}$.

Абел Февр (Faivre Abel): 5. Польски ужици (Plaisirs champétres), платно, потписано доле десно, $26 \times 20 \mathrm{~cm}$ (5о франака). 6. Сан (Sommeil), овално платно, потписано доле лево, $43 \times 37$ cm (205 франака). 7. Сйойала у воgu (Les Pieds dans l'eau), пано, потписано доле лево, $25,5 \times 16 \mathrm{~cm} .8$. Читиане (La Lecture), пано, потписано доле лево, $25 \times 21 \mathrm{~cm}$.

Гињар Гастон (Guignard Gaston): 9. Пожар у шуми (Incendie dans la fôret), пано, темпера, потпис доле десно, $52 \times 79 \mathrm{~cm}$.

Гиње (Guignet F.): 10. Слейи (Les Aveugles), пано, потписано горе десно, $40 \times 30$ cm. 11. Кројачи (Les Couturières), платно, потписано доле лево, $71 \times 90 \mathrm{~cm}$.

Гијоман (Guillaumen): 12. Бgerьe (La Veillée) платно, потписано доле десно, $55 \times 47 \mathrm{~cm}$.

Ибелз (Ibels H.-G.): 13. Тоалетиа (La Toilette) платно, потписано доле десно, $21 \times 16 \mathrm{~cm} . \mathbf{1 4}$. Неgельа (Le Dimanche), платно, потписано доле лево, $65 \times 50 \mathrm{~cm}$.

Корочански (Korochanski): 15. Жена са корйом воћа (Femme au panier de fruits), платно, потписано доле лево, $99 \times 78 \mathrm{~cm}$ (135 франака). 16. Санарене (Songerie), платно, потписано доле десно, $50 \times 40$ cm. 17. Тий Бретианке (Туре de Bretonne), платно, потписано доле лево, $58 \times 36 \mathrm{~cm}$.

${ }^{16}$ Сви подаци о предметима заступљеним на аукцији наведени су у основном тексту те нису понављани у овом списку. Наведене цене су руком забележене у каталогу. Презимена, или имена и презимена уметника, наведена су као у каталогу: код неких је забележено само презиме, а код неких су и име и презиме. Превођење назива уметничких дела показало се деликатним јер она нису визуелно позната ни доступна. 
Едуар Мане (Manet Edouard): 18. Порӣрет̄ іосӣoђе Гијеме (Portrait de Mme Guillemet), скица, платно, $90 \times 71 \mathrm{~cm}$. На полеђини је потврда госпође Мане (2520 франака).

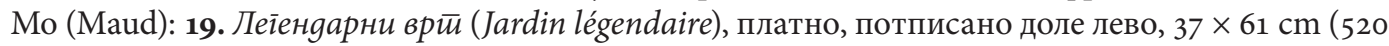
франака).

Метоа (Metoi): 2o. Канал gвориа (Le Fossé du château), платно, потписано доле лево, $56 \times 36,5 \mathrm{~cm}$ (зоо франака).

Мишети (Michetti): 21. Дивљачић (Sauvageon), платно, потписано горе десно, $45 \times 34 \mathrm{~cm}$ (6oo франака).

Нале Пусан (Nallet-Poussin): 22. Расйоgeла суйe (La Distribution de soupe), пано, потписано при средини, $40 \times 32 \mathrm{~cm}$.

Неогради (Neogrady): 23. На обоgy извора (Au bord de la source), платно, потписано доле десно, $66 \times 110 \mathrm{~cm}(120$ франака).

Озбер (Osbert): 24. Вечерни йејзаж (Рaysage du soir), пано, потписано доле лево, $37 \times 55 \mathrm{~cm}$.

Мол Нил Петерсен (Mols Niels Petersen): 25. Броgолом (Un naufrage), платно, потписано доле десно, $153 \times 235 \mathrm{~cm}$ (1050 франака).

Пон де Ejoc (Pons De Eyos): 26. Мускетиари у кабареу (Mousquetaires au cabaret), платно, $26 \times$ $35 \mathrm{~cm}$.

Фредерик Регамеј (Régamey Frédéric): 27. Пејзаж (Paysage), платно, потписано доле десно, 25 × $37 \mathrm{~cm}$.

Сасиф (Sacif): 28. Низ gереїлија (Le Train de chalands), платно, потписано доле лево, $50 \times 74 \mathrm{~cm}$. Шлајхер (Schleicher): 29. Kog üpogaвц, ogeћe (Chez le marchand d'habits), пано, потписано доле десно, $26 \times 31 \mathrm{~cm}$. 3о. Рабини коменйаришу Талмyg (Rabbins commentant le Talmud), пано, потписано доле десно, $26 \times 31,5 \mathrm{~cm}$ (Бр. 29 и 30: 220 франака).

Валадон (Valadon): 31. Цвеће (Fleurs), пано, потписано горе десно, $27 \times 22 \mathrm{~cm}$.

Воглер (Vogler): 32. Сена у Паризу (La Seine à Paris), платно, пописано доле лево, $52 \times 72 \mathrm{~cm}$.

\section{АКВАРЕЛИ}

Пол Бертон (Berton Paul): 33. Пролеће (Printemps), алегорије, потписано доле десно, $25 \times 35 \mathrm{~cm}$. Емил Бретон (Breton Emile): 34. Пејзаж (Paysage), студија, потписано доле десно, $60 \times 50 \mathrm{~cm}$. Богољубов (Bogoluboff): 35. Заанgам (марина) (Zaandam (marine)), потписано доле десно, лавирана сепија, $20 \times 30 \mathrm{~cm}$.

Луис Браун (Brown J.-Lewis): 36. Боїазов йролаз (Le Passage du gué), потписано доле лево, 43 $\times 29 \mathrm{~cm}$ (1зо франака).

Александр Бријел (Bruel Alexandre): 37. Пејзаж (Paysage), потписано доле лево, $36 \times 27 \mathrm{~cm}$.

Сезан (Cézanne): 38. Пејзаж (Paysage), $37 \times 60 \mathrm{~cm}$ (зоо франака). 39. Зелене бильке (Plantes vertes), $30 \times 26 \mathrm{~cm}$ (36о франака). 40. Брескве (Ре̂ches), $22 \times 31 \mathrm{~cm}$ (850 франака). 41. Мрйва йриpoga (Nature morte), $13 \times 19 \mathrm{~cm}$ (40о франака).

Пол Шаба (Chabas Paul): 42. Илустирација за Тицијановоі Сина (Illustration pour le Fils du Titien), потписано доле десно, $47 \times 20 \mathrm{~cm}$.

Шаперон (Chaperon): 43. Енӣеријер Свет̄е Coфuje (Intérieur de Sainte-Sophie), потписано доле лево, $35 \times 45 \mathrm{~cm}$.

Колеман (Coleman): 44. Oрағе у Ийалијu (Labour en Italie), потписано доле лево, 42,5 × $63 \mathrm{~cm}$ (250 франака).

Котан (Cottin): 45. У земли снова (Au pays des rêves), потписано доле лево, $32 \times 19 \mathrm{~cm}$. 
Де Фер (De Feure): 46. Жена са ружом (Femme à la rose), потписано десно при дну, $62 \times 47 \mathrm{~cm}$. 47. Алеїорична ілава (Tête allégorique), декорација, потписано доле десно, $56 \times 38 \mathrm{~cm}$. 48. Жена са хризаниеммама (La Femme aux chrysanthèmes), декорација, потписано доле десно, $58 \times 40 \mathrm{~cm}$. 49. Алеїорија (Allégorie), потписано доле лево, $40 \times 37 \mathrm{~cm}$. 50 . Бриж (алеїорија) (Bruges, allégorie), потписано доле десно, $77 \times 98 \mathrm{~cm}$.

Делапре (Delaspre): 51. Бар и мјузик-хол (Bar et music-hall), потписано доле десно, $35 \times 27 \mathrm{~cm}$. Анри Детуш (Detouche Henry): 52. Поврайак са Лезбоса (Retour de Lesbos), потписано доле лево, $31 \times 46 \mathrm{~cm}$. 53. Лезбос (Lesbos), потписано доле лево, $31 \times 46 \mathrm{~cm}$.

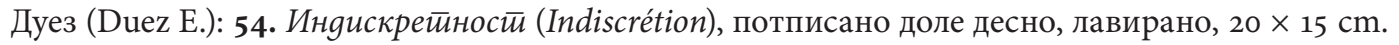
Форен (Forain): 55. Леиееза (Éventail), потписано доле лево, $18 \times 60 \mathrm{~cm}$ (240 франака).

Фортини (Fortuny): 56. Римљанка (Femme romaine), потписано доле десно, $25 \times 20 \mathrm{~cm}(180$ франака).

Фрајпонт (Fraipont G.): 57. Глоgари (Les Rongeurs), потписано доле лево, $27 \times 37 \mathrm{~cm}$.

Фријентан (Frientin): 58. Бесйосленосй (Farniente), потписано доле десно, $35 \times 26 \mathrm{~cm}$.

Гаридо (Garrido E.-L.): 59. Иcūpeg мора (Devant la mer), потписано доле десно, $41 \times 58 \mathrm{~cm}$.

Гебел (Goebel): 6о. Сйаваоница франиуске афричке иеешаguје (Chambrée de zouaves), потписано доле десно, $50 \times 65$ cm. 61. Сала са оружјем (La Salle d'armes), потписано доле лево, $40 \times 60 \mathrm{~cm}$.

Грасе (Grasset): 62. Обожаване ватире (L'adoration $d u$ feu), потписано доле десно, $40 \times 27 \mathrm{~cm}$. Албер Гијом (Guillaume Albert): 63. Шести женских ілава (Six têtes de feтmеs), потписано доле десно, $16 \times 50 \mathrm{~cm}$.

Гиран де Севола (Guirand de Scevola): 64. У кафеу (Au café), потписано доле лево, $20 \times 25 \mathrm{~cm}$.

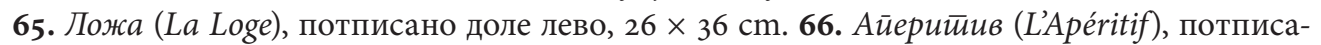
но доле лево, $24 \times 18 \mathrm{~cm}$. 67. Посмайрачи (Les Spectateurs), потписано доле лево: G. de S., $15 \times 24$ cm. 68. Айерийив (L’Apéritif), потписано доле лево: G. de S., $20 \times 31 \mathrm{~cm} .69$. Чийайелка (Liseuse), $20 \times 27 \mathrm{~cm}$. 7о. Боgинијерка (La Bodinière), потписано доле лево: G. de S., $20 \times 31 \mathrm{~cm}$.

Ги Константан (Guys Constantin): 71. Шейға (La Promenade), лавирано, $15 \times 20 \mathrm{~cm} .72$. У возилу (En voiture), лавирано, $20 \times 30 \mathrm{~cm}$. 73. Лавица (Une Lionne), лавирано, $25 \times 18 \mathrm{~cm}$. 74. У шуми (Au bois), лавирано и акцентовано, $18 \times 22 \mathrm{~cm}$. 75. Шйағолка (Femme espagnole), лавирано, $16 \times 9 \mathrm{~cm}$.

J. Е.: 76. Пејзаж (Paysage), потписано доле лево монограмом: J. Е., $50 \times 36 \mathrm{~cm}$.

Емил Жоли (Jolly Emile): 77. Појило (L’Abreuvoir), потписано доле десно, $25 \times 19 \mathrm{~cm}$. 78. Чекаюе скелещије (L’Attente du passeur), потписано доле десно, $31 \times 45 \mathrm{~cm}$. 79. Коњи у іалойy (Chevaux au galop), потписано доле десно, $34 \times 47 \mathrm{~cm}$.

Лорен Дерусо (Laurent-Desrousseaux): 8o. Пијаия (Le Marché), потписано доле десно, $27 \times 17 \mathrm{~cm}$. Менела (Mainella R.): 81. Вечерне молитиве (Prières du soir), потписано доле десно, $30 \times 17 \mathrm{~cm}$. 82. Залазак сунца (Le Couchant), потписано доле десно, $35 \times 18 \mathrm{~cm}$.

Мантегаца (Mantegazza): 83. Љубомора (Jalousie), $56 \times 39 \mathrm{~cm}$ (125 франака).

Мартан Шабли (Martin-Chablis): 84. Уїao Париза (Coin de Paris), потписано доле десно, $46 \times$ $57 \mathrm{~cm}$.

Менси (Menci): 85. Увече (En soirée), потписано доле лево, $21 \times 20 \mathrm{~cm}$.

Мез (Mes): 86. Вобан (Vauban), потписано доле лево, $27 \times 18 \mathrm{~cm}$. 
Муха (Mucha): 87-9o. Чейири іоguшға gоба (Les Quatres saisons), четири гваша, потписана, $102 \times 53 \mathrm{~cm}$ (37о франака). 91-92. Aлеїорије (Allégories), два акварела, потписано доле лево, $60 \times 31 \mathrm{~cm}$. 93. Франиуско-руске йрославе (Les Fêtes franco-russes), потписано доле десно, $27 \times 37 \mathrm{~cm}$.

Мирер (Murer): 94. Поїлеg на Борgо (Vue de Bordeaux), потписано доле лево, $26 \times 35 \mathrm{~cm}$.

Мирбах (Myrbach): 95. Бучне ӥрейирке (Escarmouche en plainte), потписао доле лево, $41 \times 21$ cm. 96. Haūag (L'attaque), потписано доле лево, $20 \times 20 \mathrm{~cm}$.

Нале Пусан (Nallet-Poussin): 97. Глава Бретианке (Tête de Bretonne), потписано горе десно, 30 $\times 25 \mathrm{~cm}$.

Алфред Пари (Paris Alfred): 98. Маневри (Les Manoeuvres), потписано доле десно, $25 \times 13 \mathrm{~cm}$. Прериози (Preriosi): 99. Турски тиріовии (Marchands turcs), потписано доле десно, $22 \times 32 \mathrm{~cm}$.

L. J. R.: 100-101. Лабуgови и йаунови (Cygnes et paons), две декоративне композиције, потписано доле лево: L. J. R., $87 \times 170 \mathrm{~cm}$.

Фредерик Регамеј (Régamey Fréd.): 102. Haūag (L’Assaut), потписано доле десно, $15 \times 22 \mathrm{~cm}$.

Рошгрос (Rochegrosse): 103. Плесови из Океаније (Danses d'Océanie), потписано доле десно, 30 $\times 41 \mathrm{~cm}$ (6оо франака).

Ромен (Romain G.): 104. Bogoūag (Chute d'eau), потписано доле десно, $37 \times 36 \mathrm{~cm}$.

Анри Сом (Somm Henri): 105. Парижанка у Јайану (Une Parisienne au Jароп), потписано доле десно, $21 \times 31 \mathrm{~cm}$.

Пјер Видал (Vidal Pierre): 106. Прекретиница (La Croisée), потписано доле десно, $27 \times 20 \mathrm{~cm}$.

Вилет (Willette): 107. Краљ йије (Le Roy boit), потписано десно при средини, $22 \times 19 \mathrm{~cm}$ (155 франака).

\section{ПАСТЕЛИ}

Анкетен (Anquetin): 108. Ogмор (Le Repos), потписано доле лево, $72 \times 103 \mathrm{~cm}$.

Бертсоен (Baertsoen A.): 109. Дуж канала (Au bord du canal), потписано доле десно, $100 \times 100 \mathrm{~cm}$ (420 франака).

Леон Бартоломе (Bartholomé Léon): 110. Енӣеријер сељанина (Intérieur de paysan), потписано доле лево: Léon Bartholomé, $77 \times 58 \mathrm{~cm}$.

Бенжаман Контан (Benjamin-Contant): 111. Глава кабилске жене (Tête de femme Kabyle), потписано доле десно: В. С., $40 \times 33 \mathrm{~cm}$.

Мадлен Карпентије (Carpentier Madeleine): 112. Преg Шереовим йлакайима (Devant les affiches de Chéret), потписано доле десно, $53 \times 37 \mathrm{~cm}$.

Кларк (Clark J.-M.): 113. Tранgафиљье (Roses trémières), потписано доле десно, $75 \times 34 \mathrm{~cm}$.

Луј Колан (Collin Louis): 114. Зимски йејзаж (Paysage d'hiver), потписано доле лево, $35 \times 50 \mathrm{~cm}$.

Дега (Degas): 115. Плесачица йри йоалет̄u (Danseuse à sa toilette), потписано горе лево, $46 \times$ $31 \mathrm{~cm}$ (1650 франака).

Десен (Dessain): 116. Пас чувар (Chien de garde), потписано доле десно, $46 \times 57 \mathrm{~cm}$.

Дилак (Dulac): 117. Opaюе (Le Labour), потписано доле лево, $38 \times 48 \mathrm{~cm}$.

Фернан Фо (Fau Fernand): 118. Касачи (Les Trottins), потписано доле десно, $45 \times 20 \mathrm{~cm}$.

Фигаци (Figazzi): 119. Зима у Милану (L'Hiver à Milan), потписано доле десно, $65 \times 40 \mathrm{~cm}$.

Пол Гоген (Gauguin Paul): 120. Глава Кинеза (Tête de Chinois) $37 \times 27$ cm. 121. Тахићанка (Tahi-

tienne), $49 \times 34$ cm. 122. Жена из Брейане (Bretonne), потписано доле лево: P. Go., $46 \times 31 \mathrm{~cm}$.

Гијомен (Guillaumin): 123. Пејзаж (Рaysage), потписано доле десно, $27 \times 38 \mathrm{~cm}$. 
АУКЦИЈА У ПАРИЗУ 1906. ГОДИНЕ СА ЗАОСТАВШТИНОМ СРПСКИХ КРАЉЕВА...

Ерман Пол (Hermann-Paul): 124. Време за куйане (L'Heure du bain), потписано доле десно, $44 \times$ $32 \mathrm{~cm}$. 125. На молу (Sur la jetée), потписано доле десно, $33 \times 24 \mathrm{~cm}$. 126. Граgска йрослава (Fête municipale), потписано доле лево, $38 \times 50 \mathrm{~cm} .127$. Пошйар (Le Facteur), потписано доле десно, $32 \times 50 \mathrm{~cm}$.

Уијар (Huillard): 128. Жена у оілеgалу (Femme au mirroir), потписано доле лево, $55 \times 36 \mathrm{~cm}$. Ибелз (Ibels H.-G.): 129. Након ӣpegaxa (Après la pose), потписано доле десно, $27 \times 17 \mathrm{~cm} .130$. Пјеро убииа (Pierrot assasin), потписано доле десно, $30 \times 18 \mathrm{~cm}$. 131. Скица (Esquisse), потписано доле десно, $27 \times 15 \mathrm{~cm}$.

Пјер Лагард (Lagarde Pierre): 132. Пойлава (L'Inondation), потписано доле лево, $61 \times 90 \mathrm{~cm}$ (225 франака).

Ламбер (Lambert L.): 133. Каранфили (Eillets), потписано доле лево, $55 \times 26 \mathrm{~cm}$.

Леви Дирмер (Levy-Dhurmer): 134. Шейть йо шуми (Promenade en fôret), потписано доле лево: L. Lévy-Dhurmer, 96,75 × $45 \mathrm{~cm}(115$ франака).

Лис (Luce): 135. Риболовна флотиа (Flotille de pêche), потписано доле лево, $22 \times 30 \mathrm{~cm}$.

Лина (Luna): 136. Алжирска везиља (Brodeuse algérienne), потписано доле лево, $36 \times 42 \mathrm{~cm}$. 137. Поврайак са йоља (Retour des champs), потписано доле десно, $50 \times 24 \mathrm{~cm}$.

Манж (Mange): 138. Глава млаgе gевојке (Tête de јеune fille), потписано доле лево, $36 \times 45 \mathrm{~cm}$. Марсел Манжан (Mangin Marcel): 139. Након куйань (Après le bain), потписано доле десно, $99 \times 80 \mathrm{~cm}$.

Мепле (Mesplès): 140. Балетиски корӣyc (Corps de ballet), потписано доле лево, $31 \times 45$ cm. 141. Плесачииа (Danseuses), потписано доле лево, $31 \times 45 \mathrm{~cm}$.

Клод Моне (Monet Claude): 142. Пејзаж (Paysage), $21 \times 32 \mathrm{~cm}$ (430 франака).

Тереза Перат (Perate Teresa): 143. Сена на Трокаgеру (зима) (La Seine au Trocadéro (hiver)), потписано доле лево, $36 \times 53 \mathrm{~cm}$. 144. Парк са овцзама (Le Parc aux moutons), потписано доле лево, $32 \times 44 \mathrm{~cm}$.

Одилон Редон (Redon Odilon): 145. Мисииччна фиіура (Figure mystique), потписано доле десно, $45 \times 37 \mathrm{~cm}$ (180 франака).

Реноар (Renoir): 146. Млаgе gевојке (Jeunes filles), потписано доле десно, $56 \times 42 \mathrm{~cm}$ (10о0 франака).

Марсел Роајер (Royer Marcel): 147. Ексиенитрична йевачица (Chanteuse excentrique), потписано доле лево, $165 \times 39 \mathrm{~cm}$.

Cepe (Serret): 148. Шейъа (La Promenade), потписано доле десно, $26 \times 34 \mathrm{~cm}$ (105 франака).

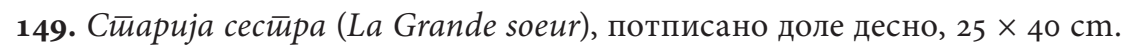

Сисли (Sisley): 150. Фарма (La Ferme), потписано доле лево, $27 \times 38 \mathrm{~cm}$ (350 франака).

Фредерик Вале Бисон (Vallet-Bisson Frédérique): 151. Букетии (Les Bouquets), потписано доле десно: Frédérique Vallet, $160 \times 95 \mathrm{~cm}$ (245 франака).

Ван Тен (Van Teyne): 152. Иїрач крикейа у Луксембуріуy (Joueurs de croquet au Luxembourg), потписано доле десно, $20 \times 33 \mathrm{~cm}$. 153. Мулен руж (Le Moulin rouge), потписано доле десно, $27 \times 49$ cm. 154. Околина Живернија (Environs de Giverny), потписано доле десно, $29 \times 43 \mathrm{~cm}$. 155. Кайеgрала (Cathédrale), потписано доле десно, $40 \times 31 \mathrm{~cm} .156$. Дереілије (Péniches), потписано доле десно, $20 \times 31$ cm. 157. Сена у Руану (La Seine, à Rouen), потписано доле десно, $28 \times 49 \mathrm{~cm}$. 158. Уїао кеја (Coin de quai), потписано доле десно, $21 \times 32 \mathrm{~cm}$. 159. Поїлеg са остирва Сен Луj (Vue de l'île Saint-Louis), потписано доле десно, $20 \times 31 \mathrm{~cm}$. 
160. Деретлија на Сени (Chaland sur la Seine), потписано доле десно, $33 \times 52 \mathrm{~cm}$. 161. Сена коg Нойр gама (La Seine à Notre-Dame), потписано доле десно, $31 \times 31 \mathrm{~cm}$.

Зандоменеги (Zandomeneghi): 162. Жена намешйа фризуру (Femme se coiffant), потписано доле десно, $25 \times 23 \mathrm{~cm}$. 163. Жена намешйа фризуру (Femme se coiffant), потписано доле десно, $25 \times 20 \mathrm{~cm}$.

\section{ЦРТЕЖИ}

Бертран (Bertrand): 164. Hезїoga (L'Accident), потписано доле десно, $25 \times 36 \mathrm{~cm}$.

Бида (Bida A.): 165. Албанаи (Albanais), потписано доле десно, $28 \times 17 \mathrm{~cm}$.

Анри Буте (Boutet Henri): 166. Берачица аліи (Cueilleuse de varechs), оловке у боји, потписано доле десно, $45 \times 30 \mathrm{~cm}$. 167. Корзети (Le Corset), цртеж акцентован сангином, потписано доле десно, $55 \times 35 \mathrm{~cm}$. 168. Рибарииза (Ре̂сheuse), потписано доле десно, $45 \times 30 \mathrm{~cm} .169$. Усйавана рибарий (Pêcheuse endormie), потписано доле лево, $40 \times 35 \mathrm{~cm}$.

Фриц Биргер (Burger Fritz): 17o. Жена која cegu (Femme assise), потписано доле лево, $29 \times 25 \mathrm{~cm}$. Кајо Жорж (Callot Georges): 171. Плакай (L’Affiche), сангин, потписано доле лево, $46 \times 32 \mathrm{~cm}$. Казан (Cazin): 172. Млин (Le Moulin), потписано доле десно, $20 \times 25 \mathrm{~cm}$.

Кутирије (Couturier): 173. Койачи (Terrassiers), потписано доле десно, $35 \times 21 \mathrm{~cm} . \mathbf{1 7 4}$. Дивей (La Divette), потписано доле десно, $32 \times 23 \mathrm{~cm}$. 175. Жена са йyøом (Femme à la houpette), потписано доле десно, $18 \times 25 \mathrm{~cm}$. 176. Жена из нароga (Femme du peuple), потписано доле десно, $31 \times 22 \mathrm{~cm}$.

Демулан (Desmoulin): 177. Жена са Јаве (Javanaises), црно мастило, потписано доле лево: J. D., $41 \times 51 \mathrm{~cm}$.

Гистав Доре (Doré Gustave): 178. Вешӣuие око ват̄pe (Sorcières autour d’un feu), скица, потписано доле лево, печат продаје, $77 \times 56,5 \mathrm{~cm}$ (115 франака).

Дилак (Dulac): 179. Cйлав (La Péniche), оловке у боји, потписано доле лево, $31 \times 47 \mathrm{~cm}$.

Фоше (Fauche): 18o. Cйyguja жене (Étude de femme), сангин, потписано горе десно, $40 \times 30 \mathrm{~cm}$.

Албер Гијом (Guillaume Albert): 181. Вернисаж (Vernissages), три акцентована цртежа, потписано доле десно, $41 \times 30 \mathrm{~cm} . \mathbf{1 8 2 - 1 8 4}$. Ивон и Гасйон (Yvonne et Gaston), серија од три цртежа пером, потписана, $37 \times 27 \mathrm{~cm}$.

Еле (Helleu): 185. Главе-сйuguje (Têtes d'étude), цртеж акцентован сангином, потписан доле десно, $30 \times 46 \mathrm{~cm}$ (100 франака).

Ерман Пол (Hermann-Paul): 186. Боравак (Villégiature), потписано доле десно, $33 \times 30 \mathrm{~cm}$.

Ибелз (Ibels H.-G.): 187. Ивети Жилбер (Yvette Guilbert), цртеж, акцентован, потписано доле лево, $60 \times 46 \mathrm{~cm}$.

Жанио (Jeanniot): 188. Две č̄uguje (Deux études), цртежи, акцентовани, потписани (један: доле лево, други: десно, у средини), $36 \times 15 \mathrm{~cm}$.

Моран (Maurin): 189. Жена са тавором (Femme à la cuvette), цртеж акцентован оловкама у боји, потписано доле десно, $60 \times 40 \mathrm{~cm}$.

Мирбах (Myrbach): 19o. Тоалейа (La Toilette), цртеж пером, потписано доле лево, $20 \times 15 \mathrm{~cm}$. 191. Кафе-кониерй (Café concert), цртеж пером, потписано доле лево, $12 \times 20 \mathrm{~cm}$.

Анри Пиј (Pille Henri): 192. Хала (La Halle), цртеж пером, потписано доле десно, $29 \times 20 \mathrm{~cm}$.

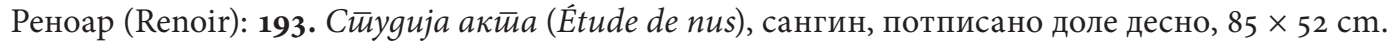
Пол Ренуар (Renouard Paul): 194. Г. йреgсеgник (M. le Président), цртеж, потписано лево, при дну, $33 \times 22$ cm. 195. Минисйров врайар (L’Huissier du ministre), цртеж, потписано горе 
АУКЦИЈА У ПАРИЗУ 1906. ГОДИНЕ СА ЗАОСТАВШТИНОМ СРПСКИХ КРАЉЕВА...

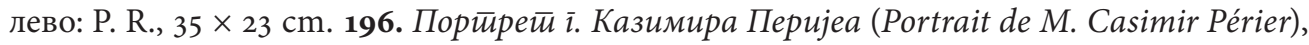
$32 \times 23 \mathrm{~cm}$.

Мануел Роб (Robbe Manuel): 197. Улица (La Rue), цртеж мастилом, потписано доле лево, 42 $\times 31 \mathrm{~cm}$.

Редел (Roedel): 198. Разіоовор у раяионици (Propos d'atelier), потписано доле десно, $30 \times 30 \mathrm{~cm}$. 199. Тріоваи „мачијим месом” (Le Marchand de „cat's теat”), потписано доле десно, цртеж пером, акцентован, $34 \times 23 \mathrm{~cm}$.

Стајнлен (Steinlen): 2oо. Прва тьубав (Premier amour), цртеж пером, акцентован оловком у боји, потписан доле ка десној страни, $34 \times 38 \mathrm{~cm}$. 201. Исйовесй (L’Aveu), цртеж пером, потписан доле ка левој страни, $38 \times 32 \mathrm{~cm}$ (14 франака). 202. На улици (Dans la rue), цртеж пером акцентован оловком у боји, потписан доле лево, $36 \times 14 \mathrm{~cm}$.

Валадон (Valadon): 203. Ogмор (Repos), цртеж у боји, потписано горе десно, $49 \times 27 \mathrm{~cm}$.

Вале (Vallet): 204. На йркама (Aux courses), цртеж пером, потписан доле у средини, $23 \times 27 \mathrm{~cm}$.

Фредерик Вале Бисон (Vallet-Bisson Frédérique): 205. Парижанка (Parisienne), потписано доле десно, $36 \times 26 \mathrm{~cm}$.

Жан Вебер (Veber Jean): 206. Жири конзерватиоријума (Le Jury du Conservatoire), цртеж пером, потписано доле десно: J. V., 94., $13 \times 48 \mathrm{~cm}$.

Вомрат (Womrath): 207. Камиј (Camille), цртеж пером, $58 \times 28 \mathrm{~cm}$.

\section{ГРАФИКЕ}

Дега (Degas): 208. Тоалейа (La Toilette), отисак акцентован пастелом, потписано доле на маргини, $21 \times 17 \mathrm{~cm}$. 209. Жене (Femmes), отисак, потписано доле десно, $20 \times 26 \mathrm{~cm}$.

\section{НЕКАТАЛОГИЗОВАН МАТЕРИЈАЛ}

210. Слике, акварели итд.

\section{ИЗВОРИ}

Интернет презентација Националне библиотеке Француске у Паризу: <https://catalogue.bnf. fr/ark:/12148/cb36524574c> 10. 12. 2020.

Интернет презентација аукцијске куће Садеби (Sotheby's):

$<$ https://www.sothebys.com/en/auctions/ecatalogue/2018/impressionist-modern-art-evening-saleno9930/lot.59.html> 17. 12. 2020.

$<$ http://www.sothebys.com/ru/auctions/ecatalogue/2009/impressionist-modern-art-evening-saleno 8587/lot.23.pricehl.html> 17. 12. 2020.

La Cronique des arts et de la curiosité, Paris, 3. 2. 1906: 2. <https://gallica.bnf.fr/ark:/12148/bpt6k62054938/f42.item.r=milan\%2oet\%2oalexandre.zoom > 28. 10. 2020.

Le Journal des arts, 31. 1. 1906: 4. <https://www.retronews.fr/journal/le-journal-des-arts/31-jan-1906/ 2163/4202009/4> 17. 12. 2020.

Le Journal des arts, 3. 2. 1906: 4. <https://www.retronews.fr/journal/le-journal-des-arts/o3-feb-1906/ 2163/4202007/4> 12. 12. 2020. 
Le Journal des arts, 7. 2. 1906: 4. <https://www.retronews.fr/journal/le-journal-des-arts/o7-feb-1906/ 2163/4202055/4> 12. 12. 2020.

Le Journal des arts, 10. 2. 1906: 1. <https://www.retronews.fr/journal/le-journal-des-arts/10-feb-1906/ 2163/4202057/3> 12. 12. 2020.

Le Journal des arts, 14. 2. 1906: 1, 4. <https://www.retronews.fr/journal/le-journal-des-arts/14-fevrier1906/2163/4202121/4> 16. 11. 2020.

LOCHARD, Fernand. Reproductions d'œuvres d'Édouard Manet. Paris: 1883-1884. [album de photos] <https://gallica.bnf.fr/ark:/12148/btv1b84329137> 12. 1. 2021.

\section{ЛИТЕРАТУРА}

ANONYME. "Les dernières épaves d'une royauté." Le matin (17. 2. 1906a): 2. <https://gallica.bnf.fr/ark: /12148/bpt6k5678810/f2.item.zoom> 2. 10. 2020.

AnONyme. "Ouvenirs du konak." Le Petit Parisien (18. 2. 19066): 2. <https:/gallica.bnf.fr/ark:/12148/ bpt6k562064k/f2.item.zoom> 2. 10. 2020.

Anonyme. "Mouvement des arts. Succession des rois Milan et Alexandre de Serbie." La Chronique des arts et de la curiosité (24. 2. 1906B): 64. <https://gallica.bnf.fr/ark:/12148/bpt6k6205460w/ f8.item.zoom> 2. 10. 2020.

БошњАК, Татјана. „Француско сликарство у Београду, формирање и улога јавне колекције.” Зборник Наровног̄ музеја (ВоŠNJAк, Tatjana. "French Painting in Belgrade, The formation and the role of a public collection." Journal of the National Museum) XIX/2 (2010): 501-533. $<$ http://www.narodnimuzej.rs/wp-content/uploads/2018/o6/Zbornik-Narodnog-muzeja-u-Beogradu-19.pdf $>$ 15. 9. 2020.

VAllemont. "Les grandes ventes, La collection des rois Milan et Alexandre de Serbie." Le Figaro (17. 2. 1906): 5. <https://gallica.bnf.fr/ark:/12148/bpt6k28726ox/f5.item.zoom> 12. 9. 2020.

VENTURI, Marcello. Sandra Orienti. L'opera pittorica di Edouard Manet. Milano: Rizzoli, 1967.

Vollard, Ambroise. Paul Cézanne. Paris: Ambroise Vollard, 1915. <https:/gallica.bnf.fr/ark:/12148/ bpt6k9693136n> 16. 9. 2020.

VOLLARD, Ambroise. Souvenirs d'un marchand de tableaux. Paris: Albin Michel, 1937. <https://gallica. bnf.fr/ark:/12148/bpt6k9689085c> 14. 9. 2020.

ВукЕЛИЋ, Дејан. „Аукцијски заборав: питање отуђене и експатрисане заоставштине династије Обреновић." Зборник Музеја йрименене уметиностии (VUKELIĆ, Dejan. "Auction.induced forgetting: the Question of Alienated and Expatriated Legacy of the House of Obrenović." Journal of the Museum of applied art) XIII (2017): 9-21. <https://mpu.rs/zbornik/pdf/zbornik 13/4.pdf> 21. 10. 2020.

ВукЕлић, Дејан, Јелена Пераћ, Владимир Томић. Сйари конак: заборављени беоіраgски gвор [каталог]. Београд: Музеј града Београда - Музеј примењене уметности (VuKELIĆ, Dejan, Jelena Perać, Vladimir Tomić. Old konak: forgotten Belgrade court [catalogue]. Belgrade: Belgrade City Museum - Museum of applied art), 2019.

DAURELlE, Jacques. "La curiosité, Quelques mots sur le roi Milan collectioneur - Collection HakkiBey: objets d'Orient et divers - Collection Garié: objets du Japon.” Mercure de France (15. 3. 1906): 
312-314. <https://www.retronews.fr/journal/mercure-de-france/15-mars 1906/118/2617635/ 156 ?from $=\% 2$ Fsearch\%23allTerms\%3Dvente\%2520roi\%252omilan\%26sort\%3 Dscore\% 26publishedBounds\%3Dfrom\%26indexedBounds\%3D from\%26page\%3 D1\%26searchIn\%3 Dall\% 26total\% 3 D 374020\&index=12> 16. 10. 2020.

Dechamps, Léon et al. Alphonse Mucha et son oeuvre. Paris: La Plume, 1897. <https://archive.org/ details/frick-31072001412883/page/n33/mode/2up> 8. 12. 2020.

Catalogue des Tableaux et Pastels Composant la Collection de Theodore Duret. Paris: Galerie Georges Petit, 1894. <https://archive.org/details/duretloogale/page/16/mode/2up> 17. 12. 2020.

Claretie, Jules. "La vie à Paris." Le Temps (9. 3. 1906): 2. <https://gallica.bnf.fr/ark:/12148/bpt6k238551z/ f2.item.zoom> 10. 11. 2020.

Koechlin, Raymond. "Étienne Moreau-Nélaton." Gazette des beaux-arts Tome XV (janvier 1927): 317-320. <https://gallica.bnf.fr/ark:/12148/bpt6k6103614g/f352.item> 7. 12. 2020.

КРСтИЋ-ФАЈ, Гордана. „Обреновићи у јавним збиркама Француске.” У: Обреновићи у музејским и gруїим збиркама Србије и Евройе. Том III. Горњи Милановац: Музеј рудничко-таковског краја (KRSTIĆ-FAYE, Gordana. "The House of Obrenović in public collections of France." Records Concerning the House of Obrenović in Museums and Other Collections of Serbia and Europe. Tome III. Gornji Milanovac: Museum of Rudnik and Takovo Region), 2015, 271-299.

LANG. "Art et curiosité." Le Journal (17. 12. 1932): 2. <https://gallica.bnf.fr/ark:/12148/bpt6k7630699w/ f2.image.r=vente\%2oroi\%2omilan?rk=107296;4> 2. 11. 2020.

Le Diable Boiteux. "Echos, Vente rouge." Gil Blas (8. 12. 1904): 1. <https:/gallica.bnf.fr/ark:/12148/ bpt6k7536668z> 6. 10. 2020.

LE MASQUE DE FeR. „À travers Paris.” Le Figaro (15. 2. 1906): 1. <https:/gallica.bnf.fr/ark:/12148/ bpt6k287258m/f1.item.zoom> 10. 11. 2020.

LEMOISNE, Paul-André. Degas et son oeuvre. Tome I. New York: Garland Pub., 1984a. <https://books. google.rs/books?hl=sr\&id=Mw3qAAAAMAAJ\&focus=searchwithinvolume\&q=roi+milan $>$ 6. 10. 2020.

LEMOISNe, Paul-André. Degas et son oeuvre. Tome III. New York: Garland pub., 19846. <https://books. google.rs/books?hl=sr\&id=HFExAQAAIAAJ\&dq=bibliogroup\%3A"Degas+et+son+oeuvre" \& focus $=$ searchwithinvolume $\& \mathrm{q}=++582+$ roi + milan $>6.10 .2020$.

M. “Art et curiosité." Le Journal (17. 2. 1906): 2 <https://gallica.bnf.fr/ark:/12148/bpt6k7625684q/ f2.item.zoom> 27. 10. 2020.

Nachlass der Könige Milan und Alexander von Serbien: Auktion 10-16 OKtober 1905 Im Dorotheum, K. K. Verstigerungsamt [catalogue]. Wien: Dorotheum, 1905. <https://digitalna.nb.rs/wb/NBS/Knjige/razno/DM_2151\#page/o/mode/1up> 7. 12. 2020.

Petitjean, Henri. "Souvenirs du konak." Le Petit Parisien (17. 2. 1906): 4. <https://gallica.bnf.fr/ ark:/12148/bpt6k5620636/f4.item.zoom> 16. 11. 2020.

Rabinow, Rebecca A., Jane S. Warman. “Chronologie.” Dans: RoQueberT, Anne (dir.) et al. De Cézanne à Picasso, chefs-d'oeuvre de la galerie Ambroise Vollar [catalogue]. Paris: Musée d'Orsay, 2007, 208-245.

TABARANT, Adolphe. Manet et ses oeuvres. Paris: Gallimard NRF, 1947. <https://gallica.bnf.fr/ark: /12148/bpt6k3355243p> 12. 1. 2021. 
TABLEAUX MODERNES, aquarelles, pastels, dessins, objets variés, provenant des successions des Rois Milan et Alexandre de Serbie: Vente des 16 et 17 février 1906 Hotel Drouot [catalogue]. Paris: Drouot, 1906. <https://gallica.bnf.fr/ark:/12148/bpt6k1245478n/f6.item.texteImage> 5. 1. 2021.

FlÛTE. "Nos échos, Collection royale." La Presse (16. 2. 1906): 2. <https://gallica.bnf.fr/ark:/12148/ bpt6k603658n/f4.item.r=drouot.zoom > 8. 12. 2020.

\section{Gordana S. Krstić Faye \\ AUCTION SALE OF SERBIAN KINGS MILAN AND ALEKSANDAR OBRENOVIĆ HERITAGE IN PARIS IN 1906}

Summary

Serbian King Aleksandar and Queen Draga Obrenović were killed in 1903. Part of their movable heritage was later sold abroad, at auctions. The first auction in Paris (February 16-17, 1906, Hotel Drouot) included modern paintings, watercolors, pastels, drawings, graphics, and various other objects. There were 210 catalogued works of art (32 paintings, 75 watercolors, 56 pastels, 44 drawings, 2 graphics, and a group of non-catalogued materials: paintings, watercolors, etc.). There were 8 various other objects (porcelain, silverware, furniture, etc.). Among paintings, there were Portrait of Mme Guillemet by Edouard Manet and On the coasts of Iceland by Yvan Aivasovsky, watercolors by Paul Cézanne: Landscape, Green Plants, Peaches, and Still Life, then Allegories, FrancoRussian Celebrations and Four Seasons by Alphonse Mucha, pastels Dancer Combing Her Hair by Edgar Degas, Head of a Chinese, Tahitian Women, and Women from Bretagne by Paul Gauguin, then Landscape by Claude Monet, Young Girls by Auguste Renoir, The Farm by Alfred Sisley, etc. Among drawings, there were Witches Around a Fire by Gustave Doré, Nude Study by Auguste Renoir, and The Rest by Suzanne Valadon, while among graphics there were La Toilette and Women by Edgar Degas. Ambroise Vollard bought pastels by Renoir, Serret, Bartholomé, two graphics by Degas and a group of non-catalogued material. The Portrait of Mrs. Guillemet by Eduard Mane reached the highest sum of 2,520 francs. Étienne Moreau-Nélaton, a well-known Parisian collector, donated his auction catalogue to the National Library of France in Paris. The Obrenović collection was mostly formed by Milan Obrenović after his abdication in 1889, when he lived in Paris as "Count of Takovo". He used to buy works of contemporary artists, with no intention of speculating, and he was especially interested in advanced art. He formed a heterogeneous collection whose content was mostly sold out after 1903, something was donated, or maybe stolen or destroyed. The catalogue of the auction in Paris in 1906 is an important document that testifies about the content of the collection of King Milan Obrenović that has not yet been researched in detail.

Keywords: auction sale of Serbian kings Milan and Aleksandar Obrenović heritage in Paris, King Milan Obrenović, Count of Takovo, art collection of Obrenović dynasty, Ambroise Vollard, Étienne Moreau-Nélaton. 